\title{
DAMPAK PEMALSUAN DATA IDENTITAS ADMINISTRASI PENIKAHAN TERHADAP STATUS HUKUM PERNIKAHAN INDONESIA DAN PERSPEKTIF HUKUM ISLAM
}

\author{
Ahmad Dailami, Rumba Triana, Arijulmanan \\ (Staff Yayasan Baitul Maal BRI Pusat) \\ (Dosen Tetap STAI Al-Hidayah Bogor) \\ (Dosen Tetap Prodi Al-Ahwal Al-Syakhsiyyah STAI Al-Hidayah Bogor) \\ Adaelami@ymail.com
}

Received: 02-05-2018, Accepted: 23-05-2018, Published: 01-06-18

\begin{abstract}
Abtract
Marriage is the Islamic Shari'ah, where Allah S.W.T. has made this Shari'a to create the goal of sakinah, mawaddah, rahmah. The Indonesian government considers it very important about marriage and therefore national marriage legislation is enacted. So issued law No. 1 of 1974 on marriage and government regulation No. 9 of 1975 on the implementation of law No. 1 of 1974 which regulates the problem of marriage. And to keep the destination of this marriage then the government ordered the public to record every marriage that took place in the Ministry of Religious Affairs through the Office of Religious Affairs (KUA) located in the District. As stipulated in the Compilation of Islamic Law article 2 concerning Marriage Registration is "recording of marriage of those who hold their marriage according to Islamic religion, performed by the appointing officer as meant in Law Number 32 Year 1954 concerning Recording of Marriage, Divorce and Reconciliation. But even so unregistered marriages are still considered valid by marriage law in Indonesia, and can be canceled with a 3rd party lawsuit, as for Islamic law marriages that take place without recording can not be undone.
\end{abstract}

Keywords: Marriage, Identity Data Fraud

\begin{abstract}
Abstrak
Pernikahan merupakan syariat Islam, dimana Allah S.W.T. telah menjadikan syariat ini untuk menciptakan tujuannya yaitu sakinah, mawaddah, dan rahmah. Pemerintah Indonesia memandang sangat penting tentang pernikahan oleh sebab itu dibuatlah perundang-undangan perkawinan yang berlaku secara Nasional. Maka dikeluarkanlah undang - undang Nomor 1 Tahun 1974 tentang perkawinan dan peraturan pemerintah Nomor 9 tahun 1975 tentang pelaksanaan undang-undang Nomor 1 Tahun 1974 yang mengatur masalah pekawinan. Dan untuk menjaga tujuan pernikah ini maka pemerintah memerintahkan kepada masyarakat untuk mencatatkan setiap pernikahan yang berlangsung di Departemen Agama melalui Kantor Urusan agama (KUA) yang berada di wilayah Kecamatan. Sebagaimana yang diatur dalam Kompilasi Hukum Islam pasal 2 tentang Pencatatan Pernikahan yaitu "pencatatan perkawinan dari mereka yang melangsungkan perkawinannya menurut agama islam, dilakukan oleh pegawai pencatat sebagaimana dimaksudkan dalam Undang-undang Nomor 32 Tahun 1954 tentang Pencatatan Nikah, Talak dan Rujuk. Tapi walaupun demikian pernikahan yang tidak tercatat tetap dianggap sah oleh hukum pernikahan di Indonesia, dan dapat dibatalkan dengan gugatan pihak ke 3, adapun secara hukum Islam pernikahan yang berlangsung tanpa pencatatan tidak bisa dibatalkan.
\end{abstract}

Kata Kunci: Pernikahan, Pemalsuan Data Identitas 


\section{Pendahuluan}

Manusia adalah makhluk social, makhluk yang kecendrungan untuk hidup bersama, berkelompok dan berteman dengan manusia lainnya. Dalam menjalani kehidupannya manusia membutuhkan orang lain untuk berinteraksi. Diantara yang dibutuhkan manusia adalah teman hidup lawan jenis yang satu visi dan misi dalam menjalani kehidupannya, diantara cara mendapatkan teman hidup adalah dengan melakukan pernikahan.

Penikahan merupakan peristiwa penting dalam kehidupan manusia, karena pernikahan menjadi proses yang sakral dalam kehidupan seseorang, pada umumnya pernikahan selalu berhubungan dengan kaidah-kaidah agama, karena setiap agama memiliki ketentetuan hukum tertentu dalam hal pernikahan. Dari pernikahan timbul hubungan suami istri dan kemudian hubungan antara orang tua dan anak-anak nya. Dan timbul pula hubungan kekeluargaan sedarah dan semanda. Karena itu pernikahan mempunyai pengaruh yang sangat luas, baik dalam hubungan kekeluargaan pada khususnya, maupun dalam kehidupan bermasyarakat dan bernegara pada umumnya, maka hendaknya segenap bangsa Indonesia mengetahui seluk beluk berbagai peraturan hukum pernikahan, agar mereka memahami dan dapat melangsungkan pernikahan sesuai dengan peraturan yang berlaku demikian pula dalam memelihara kelangsungan dan akibat dalam pernikahan. $^{1}$

${ }^{1}$ A. Rahman dan Drs. Ahmad Sukarja Bakri. 1993. Hukum Perkawinan Menurut Islam, Undang
Islam adalah agama yang rahmatan lil a'alamin, menjadi rahmat bagi semua umat manusia, seluruh aturannya dimaksudkan untuk kemaslahatan umat manusia. Salah satu perhatian islam adalah mengatur tentang kaidah-kaidah perkawinan, diantara nya adalah mengatur bagaimana cara mencari pasangan hidup yang baik, dan bagaimana cara pelaksanaan perkawian yang baik. Hal tersebut berguna untuk kemaslahatan manusia agar menciptakan keluarga yang sakinah, mawahdah, dan rahmah.

Pernikahan merupakan sesuatu yang sangat di anjurkan didalam Islam, karena pernikahan meruapakan cara menjaga diri dan menyelamatkan masyarakat serta memperbanyak kaum muslimin. ${ }^{2}$ Rasulullah shalallahu a'alaihi wasalam bersabda "wahai para pemuda, barang siapa diantara kalian sudah mempunyai kemampuan, maka hendaklah kalian menikah, karena hal itu memelihara penglihatannya, dan menjaga kehormatannya, barang siapa yang belum mempunyai kemampuan maka hendaklah dia berpuasa, karena puasa adalah perisai."3

Islam adalah agama yang fitrah, dan manusia diciptakan sesuai fitrah ini. Karena itu Allah menyuruh mereka menghadapkan diri ke agama yang fitrah, agar tidak terjadi penyelewengan dan penyimpangan sehingga tetap berjalan

-Undang Perkawinan dan Hukum Perdata BW. Jakarta: PT. Hidakarya Agung. hlm. 1.

2 Abdurahman Ash-shabihi. 2003. Petunjuk praktis dan fatwa pernikahan. Jakarta: Najla Press. Cet. Ke-1. hlm 26.

${ }^{3}$ Ibnu Hajar Al-asqalani. 2013. Bulughul Maram dan Dalil-dalil Hukum. Jakarta: Gema Insani. Cet-1 hlm. 421. 
diatasnya. Pernikahan adalah fitrah manusia. Oleh karena itu Islam menganjurkan umatnya menikah, karena pernikahan termasuk gharizah insaniyah (naluri kemanusiaan). Apabila naluri ini tidak dipengaruhi dengan jalan yang sah, yaitu pernikahan maka manusia pun mencari jalan-jalan syaitan yang akan menjerumuskan kelembah hitam. Firman Allah dalam Al-Qur'an Surat Ar-Rum: 30

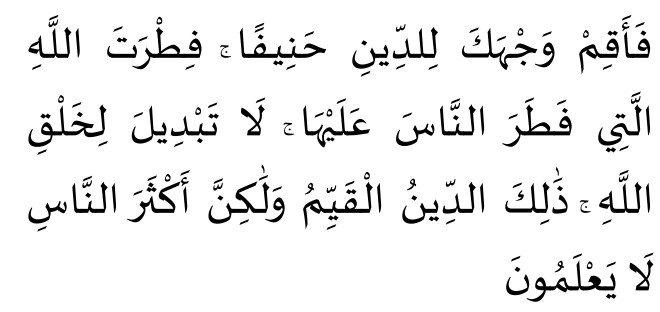

Artinya: "Maka hadapkanlah wajahmu dengan lurus kepada agama (islam) Sesuai fitrah Allah, disebabkan dia menciptakan manusia menurut fitrah itu. Tidak ada perubahan pada ciptaan Allah itulah agama yang lurus tetapi kebanyakan manusia tidak mengetahui," (QS. $\operatorname{Ar}-\operatorname{Rum}(30): 30)^{4}$

Pernikahan adalah salah satu nikmat dari Allah atas hambanya, menjaga kehidupan diatas bumi ini apabila kosong dari kesenangan akan menjadi gersang, karena itu lah hikmah Allah meliputi seluruh insting kelestarian hidup dengan sebab-sebab kesenangan. Merenungkan hikmah ini akan menjadikan manusia berada dalam tujuan yang jelas, kesenangan bukan merupakan tujuan itu sendiri, namun kesenangan adalah sarana menuju pada tujuan - tujuan yang mulia,

4 Al-Qur'an dan Terjemah. Jakarta: Departeman Agama. hlm 645. karena cabang yang baik itu tidak akan muncul kecuali dari yang baik pula. Sebagaiman Firman Allah dalan Surat ArRum ayat 21:

$$
\begin{aligned}
& \text { وَمِنْ آيَاتِاِ أَنْ خَلَقَ لَكُمْ مِنْ أَنْفُسِكُمْ }
\end{aligned}
$$

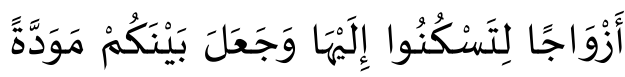

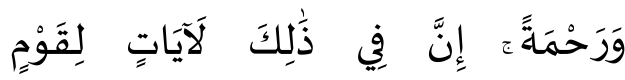

$$
\begin{aligned}
& \text { يَتَفَكََّرونَ }
\end{aligned}
$$

"Dan diantara tanda-tanda kekuasaannya ialah dia menciptakan untukmu istri-istri dari jenis kalian sendiri, supaya kalian cenderung dan merasa tentram kepadanya. Dan dijadikannya di antara kalian rasa kasih sayang, sesungguhnya pada yang demikian itu benar-benar terdapat tanda- tanda bagi kaum yang berfikir."(QS. Ar-Rum (30): 21) ${ }^{5}$

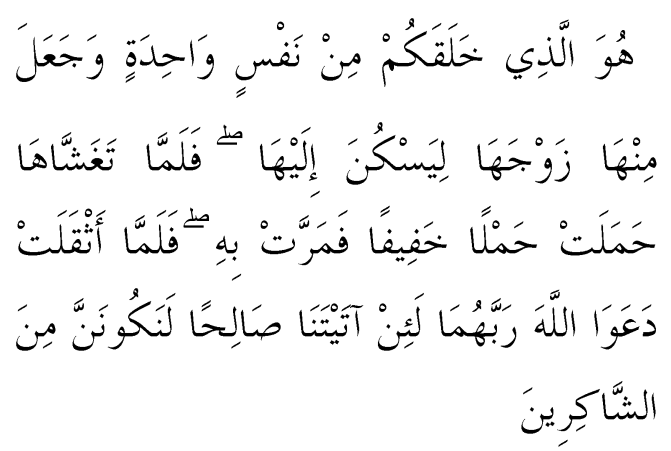

"Dialah yang menciptakan kamu dari diri yang satu dan dari padanya, dia menciptakan istrinya, agar dia merasa senang kepadanya." (AlA'raf: 189$)^{6}$

Pemerintah Indonesia memandang sangat penting tentang pernikahan oleh

\footnotetext{
${ }^{5}$ Al-qur'an dan Terjemah. hlm 644.

${ }^{6}$ Al-qur'an dan Terjemah. hlm 253.
} 
sebab itu dibuatlah perundang-undangan perkawinan yang berlaku secara Nasional. Maka dikeluarkanlah undang-undang Nomor 1 Tahun 1974 tentang perkawinan dan peraturan pemerintah Nomor 9 tahun 1975 tentang pelaksanaan undang-undang Nomor 1 Tahun 1974 yang mengatur masalah pekawinan.

Pernikahan di Indonesia harus dicatatkan di Departemen Agama melalui Kantor Urusan agama (KUA) yang berada di wilayah Kecamatan. Sebagaimana yang diatur dalam Kompilasi Hukum Islam pasal 2 tentang Pencatatan Pernikahan yaitu "pencatatan perkawinan dari mereka yang melangsungkan perkawinannya menurut agama islam, dilakukan oleh pegawai pencatat sebagaimana dimaksudkan dalam Undang-undang Nomor 32 Tahun 1954 tentang Pencatatan Nikah, Talak dan Rujuk. ${ }^{7}$

Kompilasi Hukum Islam (KHI) pasal 3 yang berbunyi "setiap orang yang akan melangsungkan perkawinan memberitahukan kehendaknya itu kepada pegawai pencatat tempat perkawinan akan dilangsungkan." dan pasal 6 yang berbunyi "pegawai pencatat yang menerima pemberitahuan kehendak melangsungkan perkawinan, meneliti apakah syarat-syarat perkawinan telah terpenuhi dan apakah tidak terdapat halangan perkawinan menurut undang-undang." 8

Pemberitahuan kehendak nikah dapat dilakukan oleh calon mempelai atau orang tua wakilnya dengan membawa surat-surat yang diperlukan. Namun apabila calo

7 2013. Kompilasi Hukum Islam. Fokusindo Mandiri: Bandung. hlm.130.

8 2013. Undang-undang Kompilasi Hukum Islam. Jakarta: Fokusindo Mandiri. hlm. 131. pengantin dalam keadaan tertentu maka harus melampirkan surat-surat yang dibutuhkan sebagai berikut:

1. Surat izin orang tua (formulir model $\mathrm{N}-5$ ) bagi calon pengantin yang belum mencapai umur 21 tahun. Dalam hal tidak ada izin dari kedua orang tua atau walinya memerlukan izin dari pengadilan agama

2. Surat dispensasi dari pengadilan agama bagi calon pria yang belum mencapai umur 19 tahun bagi calon pengantin wanita yang belum mencapai umur 16 tahun

3. Surat izin poligami dari pengadilan bagi calon pengantin pria yang akan beristri lebih dari Satu

4. Surat izin nikah dari kesatuan atau atasan bagi calon pengantin anggota TNI/POLRI atau pejabat tertentu yang kepadanya diwajiban agar memperoleh izin terlebih dahulu dari pejabat yang berwenang memberikan izin.

5. Akta cerai atau buku pendaftaran talak atau buku pendaftaran cerai jika calon pengantin seorang janda atau duda karena perceraian.

6. Akta kematian atau surat kematian yang dibuat oleh kepala desa atau lurah (Formulir Model N-6) jika calon pengantin seorang janda atau duda karena kematian suami/istri.

7. Surat dispensasi dari camat, jika rencana akad nikah akan dilangsungkan diluar domisili calon pengantin wanita.

8. Surat keterangan tidak mampu (SKTM) bagi calon pengantin yang 
tidak sanggup membayar biaya nikah.

9. Surat rekondasi dari KUA domisili pengantin wanita jika akad nikah akan dilakukan diluar domisili calon pengantin wanita. ${ }^{9}$

Pada prakteknya permasalahan yang muncul di KUA adalah masalah ketidak akuratan data identitas calon pengantin.

Dengan adanya pemalsuan identitas dapat menyebabkan kerugian bagi masingmasing pihak. Baik dari pihak keluarga calon pengantin maupun bagi lembaga pemerintah itu sendiri. Maka akan ada kesan dengan adanya pemalsuan data identitas ini terjadi karena tidak berfungsinya pengawasan baik dari pihak keluarga maupun dari pihak pejabat berwenang sehingga perkawinan itu bisa terlaksana.

Penulis menganggap bahwa permasalahan diatas cukup menarik untuk dikaji dan diteliti karena setelah melakukan study review penulis berkeyakinan bahwa kasus yang akan diteliti sangat berbeda dengan penelitian-penelitian yang sudah pernah dilakukan.

Islam adalah agama yang fitrah, dan manusia diciptakan sesuai fitrah ini. Karena itu Allah menyuruh mereka menghadapkan diri ke agama yang fitrah, agar tidak terjadi penyelewengan dan penyimpangan sehingga tetap berjalan diatasnya. Pernikahan adalah Fitrah Manusia, Islam menganjurkan umatnya

${ }^{9}$ Direktorat Jendral Bimbingan Masyarakat Islam dan Penyelangaraan Haji. 2005. Tatacara dan Mekanisme Pengurusan Pekawinan dan Rujuk di Indonesia. Jakarta: Departemen agama RI. hlm 5. untuk menikah, karena nikah termasuk Gharizah Insaniyah (naluri kemanusiaan). Apabila naluri ini tidak dipenuhi dengan jalan yang sah, yaitu pernikahan, maka ia pun mencari jalan-jalan syaitan yang akan menjerumuskan kelembah hitam. ${ }^{10}$ Allah berfirman dalam Surat Ar-Rum Ayat 30:

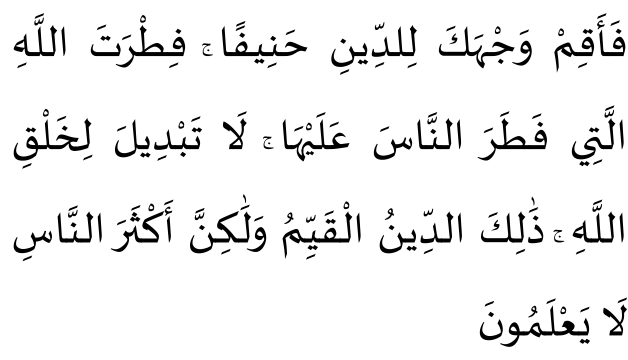

Artinya: "Maka hadapkanlah wajahmu dengan lurus kepada agama (islam) Sesuai fitrah Allah, desebabkan dia menciptakan manusia menurut fitrah itu. Tidak ada perubahan pada ciptaan Allah itulah agama yang lurus tetapi kebanyakan manusia tidak mengetahui." (QS. Ar-Rum $(30): 30)^{11}$

An-nikah menurut bahasa arab berarti adh-dham yakni menghimpun, lafadz ini dimutlakkan untuk akad dan persetubuhan. Adapun menurut syariat, pengertiannya sebagaimana dijelaskan oleh Ibnu Qudamah, "Nikah menurut syariat adalah akad pernikahan. Ketika kata nikah diucapkan secara mutlak, maka ia bermakna demikian selama tidak ada dalil yang memalingkan darinya. ${ }^{12}$

10 Yazid Abdul Qadir. 2014. Panduan Keluarga Sakinah. Jakarta: Pustaka Imam Syafi'I cet. 11 , hlm.14.

${ }^{11}$ Al-qur'an dan Terjemah. hlm 645.

12 Yazid Abdul Qadir. 2014. Panduan Keluarga Sakinah. hlm.14. 
An-nikah secara etimologi adalah penyatuan, seakan-akan seorang suami menggabungkan (menyandarkan) istrinya kedadanya, sebagaimana seorang ibu menyandarkan anaknya kedadanya dengan perasaan kasih sayang dan kemesraan serta kelembutan. Nikah juga dinisbatkan pada masalah akad dan watha (persetubuhan). Adapun secara syariat nikah atau zawaj adalah akad (perjanjian) yang memberikan kepada salah satu dari sepasang suami istri hak untuk bersetubuh antara satu dengan yang lainnya secara syar'i. ${ }^{13}$

Pernikahan (Az-Zawaj) secara etimologi adalah menyepadankan antara dua benda dengan yang lainnya dan menggabungkan keduanya, yaitu keduanya menjadi pasangan setelah sebelumnya terpisah.

Pernikahan adalah salah satu yang dianjurkan didalam Islam karena merupakan bagian dari fitrah manusia. Ada beberapa dasar hukum dalam pernikahan dilihat dari Alquran dan sunnah diantanya sebagai berikut :

a. firman Allah dalam Surat Ar-rad Ayat 38

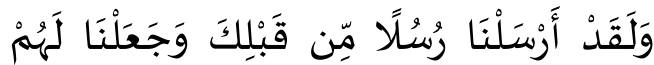

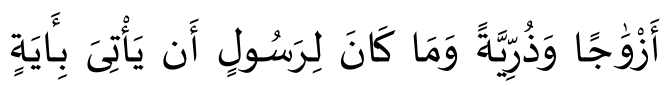

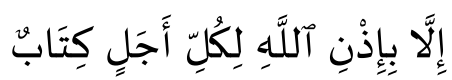

"Dan sesungguhnya Kami telah mengutus beberapa Rasul sebelum kamu dan Kami memberikan kepada mereka isteri-isteri dan keturunan. Dan tidak ada hak bagi seorang

13 Ash-shabihi, abdurahman. 2003. Risalah ilal 'arusi wa fatawa az-zawaz muasyaratu an-nisa, hlm. 23.
Rasul mendatangkan sesuatu ayat (mukjizat) melainkan dengan izin Allah. Bagi tiap-tiap masa ada Kitab (yang tertentu)

b. Firman Allah dalam Surat An-Nur ayat 32

$$
\begin{aligned}
& \text { وَ أَنْكِحُوا الََْْامى مِنْكُمْ وَ الصَّاِلِحينَ مِنْ } \\
& \text { عِبادِكُمْ وَ إِمائِكُمْ إِنْ يَكُونُوا فُقَراءَ يُفْنِهِهُ } \\
& \text { اللهُ مِنْ فَضْلِيهِ وَ اللهُ واسِعِع عَليمِ }
\end{aligned}
$$

"Dan kawinkanlah orang-orang yang sedirian diantara kalian, dan orangorang yang layak (berkawin) dari hamba-hamba sahaya kalian yang lelaki dan hamba-hamba sahaya kalian yang perempuan. Jika mereka miskin Allah akan memampukan mereka dengan kurnia-Nya. Dan Allah Maha luas (pemberian-Nya) lagi Maha Mengetahui."

c. Firman Allah dalam Surat An-Nisa Ayat 3

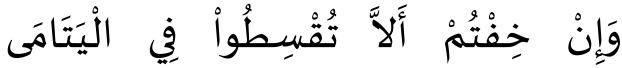

$$
\begin{aligned}
& \text { فَانكِحُواْ مَا طَابَ لَكُمَ مِنَنَ النِِّسَاء مَثْنَى }
\end{aligned}
$$

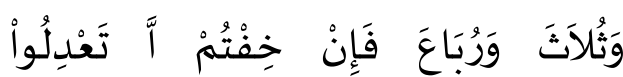

$$
\begin{aligned}
& \text { فَوَاحِدَةً أَوْ مَا مَلَكَتْ أَيْمَانُكُمْ ذَلِلكَ أَدْنَى } \\
& \text { أَلالَّ تَعَوُولُواً }
\end{aligned}
$$

"Dan jika kalian takut tidak akan dapat berlaku adil terhadap (hak-hak) perempuan yang yatim (bilamana kalian mengawininya), maka nikahilah wanita-wanita (lain) yang kalian senangi: dua, tiga atau empat. Kemudian jika kalian takut tidak akan dapat berlaku adil, maka 
(nikahilah) seorang saja, atau budakbudak yang kalian miliki. Yang demikian itu adalah lebih dekat kepada tidak berbuat aniaya".

d. Diriwayatkan oleh al-Bukhari dari 'Abdullah bin Mas'ud Radhiyallahu anhu. Ia menuturkan: "Kami bersama Nabi Shallallahu 'alaihi wa sallam sebagai pemuda yang tidak mempunyai sesuatu, lalu beliau bersabda kepada kami:

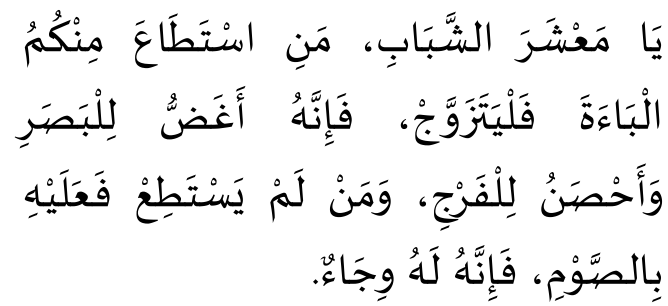

"Wahai para pemuda, barang siapa di antara kalian yang mampu menikah, maka menikahlah. Karena menikah lebih dapat menahan pandangan dan lebih memelihara kemaluan. Dan barangsiapa yang tidak mampu, maka hendaklah ia berpuasa; karena puasa dapat menekan syahwatnya (sebagai tameng)."14

Berdasarkan penjelasan diatas dapat diketahui bahwa pernikahan dalam Islam sangat dianjurkan dan disyariatkan, hal tersebut dimaksudkan untuk menjaga kelestarian manusia dan memelihara populasinya.

Hukum asal pernikahan adalah sunah, Rasulullah Salallahualaihi wasallam mengaitkan antara perintah menikah dengan isthitha'ah (kemampuan)

${ }^{14}$ Imam Al-Bukhari. 2004. Shahih Bukhari. Dar Elhadist Publishing. Juz 3 hlm.359 no.1905. secara finansial dan fisik, maka wajib bagi yang mampu untuk menikah karena ditakutkan bagi dirinya untuk berbuat zina. Karena itu, dia harus menjaga dirinya dan menjauhi dari yang haram, dan semua itu dapat terwujud hanya dengan menikah. Akan tetapi hukumnya menjadi sunnah bagi yang mampu menahan syahwatnya untuk tidak berbuat yang diharamkan. ${ }^{15}$

Islam memberikan konsep yang jelas tentang tatacara pernikahan yang berlandaskan Al-quran dan As-sunnah yang shahih, sesuai dengan pemahaman salafush shalih. Ada beberapa syarat, rukun dan kewajiban yang harus dipenuhi diantaranya sebagai berikut:

\section{a. Wali}

Wali adalah orang yang yang paling dekat dengan pihak wanita, dan orang yang paling berhak untuk menikahkan wanita merdeka adalah ayahnya, lalu kakeknya, dan seterusnya ke atas. Dan juga anak lakilakinya dan cucu laki-lakinya, kemudian saudara laki-laki seayah seibu, dan saudara laki-laki seayah, kemuadian saudara lakilaki dari seayah seibu, dan anak laki-laki dari saudara laki-laki seayah (keponakan), kemuadian paman dari pihak ayah (saudara laki-laki dari ayah ) kemudian anak-anak laki-laki dari paman tersebut, kemudian saudara laki-laki dari kakek (paman dari ayah), kemudian anak laki-laki mereka. Kemudian sulthan (penguasa) bagi wali yang tidak memiliki wali.

Ibnu Bhathal rahimahullah berkata "mereka (para ulama) ikhtilaf tentang wali.

15 Abdurahman Ash-shabihi. 2003. risalah ilal 'arusi wa fatawa az-zawaz muasyaratu an-nisa. hlm. 23 . 
Jumhur ulama diantanya adalah Imam Malik, Imam Atsauri, Imam Al-Laits, Imam Syafi'I dan imam yang lainnya, menyatakan: "Wali dalam perniakahan adalah 'Ashabah (dari pihak bapak), sedangkan paman dari saudara ibu, ayahnya ibu, dan saudara-saudara dari pihak ibu tidak memiliki hak wali. ${ }^{16}$

Disyaratkan adanya wali bagi wanita. Islam mensyaratkan adanya wali bagi wanita sebagai penghormatan bagi wanita, memuliakan dan menjaga masa depan mereka. Walinya lebih mengetahui daripada wanita tersebut. Jadi bagi wanita, wajib ada wali yang membimbing urusannya, mengurus aqad nikahnya. Tidak boleh bagi seorang wanita menikah tanpa wali, dan apabila ini terjadi maka tidak sah pernikahannya.

Tentang wali ini berlaku bagi gadis maupun janda. Artinya, apabila seorang gadis atau janda menikah tanpa wali, maka nikahnya tidak sah.Tidak sahnya nikah tanpa wali tersebut berdasarkan haditshadits di atas yang shahih dan juga berdasarkan dalil dari Al-Qur'anul Karim.

Allah Ta'ala berfirman:

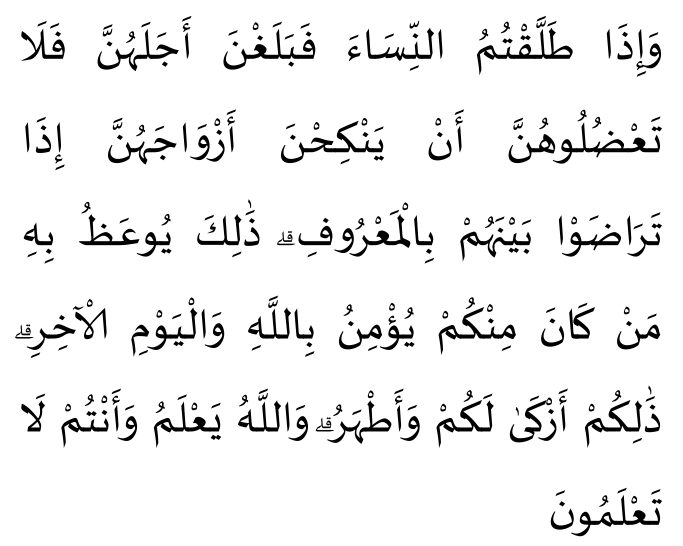

16 Yazid Abdul Qadir. 2014. Panduan Keluarga Sakinah. hlm. 92.
"Dan apabila kamu menceraikan isteri-isteri (kamu), lalu sampai masa 'iddahnya, maka jangan kamu (para wali) halangi mereka menikah (lagi) dengan calon suaminya, apabila telah terjalin kecocokan di antara mereka dengan cara yang baik. Itulah yang dinasihatkan kepada orang-orang di antara kamu yang beriman kepada Allah dan hari Akhir. Itu lebih suci bagimu dan lebih bersih. Dan Allah mengetahui, sedangkan kamu tidak mengetahui." [Al-Baqarah : 232]

Ayat di atas memiliki asbaabun nuzul (sebab turunnya ayat), yaitu satu riwayat berikut ini. Tentang firman Allah: "Maka janganlah kamu (para wali) menghalangi mereka," al-Hasan al-Bashri rahimahullaah berkata, Telah menceritakan kepadaku Ma'qil bin Yasar, sesungguhnya ayat ini turun berkenaan dengan dirinya.

Imam asy-Syafi'i rahimahullaah berkata, "Siapa pun wanita yang menikah tanpa izin walinya, maka tidak ada nikah baginya (tidak sah). Karena Nabi shallallaahu 'alaihi wa sallam bersabda, 'Maka nikahnya bathil (tidak sah).,'17

Imam Ibnu Hazm rahimahullaah berkata, "Tidak halal bagi wanita untuk menikah, baik janda maupun gadis, melainkan dengan izin walinya: ayahnya, saudara laki-lakinya, kakeknya, pamannya, atau anak laki-laki pamannya...”

Imam Ibnu Qudamah rahimahullaah berkata, "Nikah tidak sah kecuali dengan wali. Wanita tidak berhak menikahkan

17 Yazid Abdul qadir. 2014. Panduan Keluarga Sakinah. hlm. 96 
dirinya sendiri, tidak pula selain (wali)nya. Juga tidak boleh mewakilkan kepada selain walinya untuk menikahkannya. Jika ia melakukannya, maka nikahnya tidak sah. Menurut Abu Hanifah, wanita boleh melakukannya. Akan tetapi kita memiliki dalil bahwa Nabi shallallaahu 'alaihi wa sallam bersabda,

$$
\text { لاَ نِكَاحَ إِلَّ بِوَلِيّ }
$$

"Pernikahan tidak sah, melainkan dengan adanya wali."

\section{b. Meminta persetujuan pihak wanita sebelum menikah}

Pernikahan tidak sah kecuali adanya wali, maka merupakan kewajiban juga meminta persetujuan dari wanita yang berada dibawah perwaliannya. Apabila wanita tersebut seorang janda, maka diminta persetujuannya (pendapatnya) sedangkan jika wanita tersebut seorang gadis, maka diminta juga izinnya dan diamnya merupakan tanda dia setuju. ${ }^{18}$

\section{c. Mahar}

Mahar adalah sesuatu yang diberikan kepada istri berupa harta atau selainnya, dengan sebab pernikahan. Mahar adalah hak seorang wanita yang harus dibayar oleh lakilaki yang akan menikahinya. Mahar merupakan milik seorang istri dan tidak boleh seorang pun mengambilnya, baik ayah maupun yang lainnya, kecuali dengan keridhaannya. Allah subhanahu wata'ala berfirman dalam suran An-Nisa Ayat 4 :

“dan berikanlah mahar ( maskawin) kepada perempuan yang kamu nikahi sebagai

\footnotetext{
${ }^{18}$ Yazid Abdul Qadir. 2014. Panduan
} Keluarga Sakinah.hlm.96 pemberian yang penuh kerelaan.....". (QS. An-Nisa (4): 4)

Kedua pasangan sepakat untuk menghilangkan mahar, maka pernikahan mereka fasid ( Tidak sah), sebab mahar harus ada dalam sebuah pernikahan, baik yang disebutkan nominalnnya maupun yang tidak disebutkan. Dalam hal ini wanita nerhak memperoleh mahar mitsl ${ }^{19}$.

\section{d. Menghadirkan dua orang saksi}

e. Adanya ijab dan qabul yang bersambung dengan lafadz qabul (menerima) atau menikahkan. ${ }^{20}$

Menurut Undang-Undang Nomor 1 Tahun 1974 tentang perkawinan, dijelaskan tentang syarat-syarat dalam melakukan perkawinan diantaranya dalam pasal $6:^{21}$

1. Perkawinan harus didasarkan atas persetujuan kedua calon mempelai.

2. Untuk melangsungkan perkawinan seorang yang belum mencapai 21 tahun harus mendapat izin kedua orang tua.

3. Dalam hal salah seorang dari orang tua telah meninggal dunia atau dalam keadaan tidak mampu menyatakan kehendaknya, maka izin dimaksud ayat (2) pasal ini

19 Mahar Mitsl adalah mahar yang biasa diterima oleh wanita semisalnyapada waktu akad dari segi usia kecantikan, kekyaan, kecerdasan, keprawanan, kejandaan, dan lain sebagainya. Lihat Dr. Muhammad Ibrahim Al Hafnawi, Al Mausu'ah Al Fiqiyyah Al Muyassarah: Az-Zawaj, mansoura: maktabah Aliman. tt. hlm.332.

${ }^{20}$ Abdurahman Ash-shabihi .2003. Risalah ilal 'arusi wa Fatawa az-zawaz Muasyaratu AnNisa. hlm. 81.

${ }^{21}$ 2014. Undang-undang Republik Indonesia Nomor 1 tahun 1974 Tantang Perkawinan \& Kompilasi Hukum Islam, Jakarta: Graha Media Press, Cet. 1 hlm.3-4. 
cukup diperoleh dari orang tua yang masih hidup atau dari orng tua yang mampu menyam[aikan kehendaknya.

4. Dalam hal kedua orang tua telah meninggal dunia atau dalam keadaan tidak mampu untuk menyatakan kehendaknya, maka izin diperoleh dari wali, orang yang memelihara atau keluarga yang mempunyai hubungan darah dalam garis keturunan lurus keatas selama mereka masih hidup dan dalam keadaan dapat menyaatakan kehendaknya

Undang-Undang Nomor 1 Tahun 1974 Pasal 7:

a. Perkawinan haya diizinkan jika pihak pria sudah mencapai 19 tahun dan pihak wanita sudah mencapai umur 16 tahun.

b. Dalam hal penyimpangan terhadap ayat (1) pasa 1 ini dapat meminta dispensasi kepada pengadilan atau pejabat lain ditunjukan oleh kedua orang tua pihak pria maupun pihak wanita.

c. Ketentuan-ketentuan mengenai salah seorang atau kedua orang tersebut dalam pasal 6 ayat (3) dan (4) Undangundang ini, berlaku juga dalam hal permintaan dispensasi tersebut ayat (2) pasal ini dengan tidak mengurangi yang dimaksud dalam dalam pasal 6 ayat (6).

Menurut Kompilasi Hukum Islam (KHI) pasal 14, untuk melaksanakan perkawinan harus ada: ${ }^{22}$

22 2014. Undang-undang Republik Indonesia Nomor 1 tahun 1974 Tantang Perkawinan \& Kompilasi Hukum Islam. hlm. 338.
a. Calon suami;
b. Calon istri;
c. Wali Nikah;
d. Dua orang saksi;
e. Ijab dan Kabul.

Pernikahan di syariatkan untuk kemaslahatan kedua pihak, baik suami maupun istri, anak-anaknya dan masyarakat, diantaranya sebagai berikut;

a) Memenuhi tuntutan naluri manusia 23; b) Membentengi akhlak yang luhur dan menundukan pandangan ${ }^{24}$; c) Meningkatkan ibadah kepada Allah; d) Menjaga dan memelihara nasab ${ }^{25}$; e) Membentuk kelurga yang islami; f) Mendidik dan membina keturanan yang shalih. $^{26}$

Jenis penelitian yag digunakan dalam penelitian ini adalah penelitian kepustakaan (library research). Sifat penelitian yang digunakan dalam penyusunan penelitian ini adalah deskriptif analisis, yaitu penelitian dengan cara menetapkan metode - metode hukum Islam dan hukum positif yang digunakan sebagai dasar hukum, dengan tujuan untuk memecahkan masalah dampak pemalsuan data identitas pernikahan terhadap status hukum pernikahan. Dari data yang diperoleh dari penelitian diupayakan memberikan gambaran dan mengungkap

23 Yazid Abdul Qadir. 2014. Panduan Keluarga Sakinah.halm. 56.

${ }^{24}$ Muhammad Rafa'at Usman. 2017. Fiqih Khitbah dan nikah (edisi perempuan). alih bahasa Ahmad Zaeni Dachlan, Depok: Fhatan Media Prima, cet. 1 hlm. 20.

${ }^{25}$ Muhammad Rafa'at Usman. 2017. Fiqih Khitbah dan nikah (edisi perempuan). hlm. 19.

26, Abdurahman Ash-shabihi. 2003. Risalah ilal 'arusi Wa Fatawa Az-zawaz muasyaratu annisa. hlm. 34. 
berbagai faktor yang berkaitan dengan pemalsuan identitas pernikahan, kemudian dianalisis mengenai penerapan atau pelaksanaan peraturan perundang undangan dan peraturan hukum islam guna mendapatka data atau informasi mengenai status hukum yang diperoleh dari dampak pemalsuan data identitas pernikahan.

Metode pengumpulan data adalah Data Primer yakni data yang diperoleh secara langsung dari Kantor Urusan Agama (KUA) Kecamatan Citeureup .Data ini meliputi dengan hasil wawancara dengan pihak KUA Kecamatan Citeureup dan Petugas Pembantu Pencatat Nikah (P3N) yang berada di wilayah Desa di Kecamatan Citeureup. Adapun data sekunder yakni data dari studi kepustakaan yang diambil dari buku-buku, internet, dan beberapa hasil penelitian yang berhubungan dengan permasalahan pemalsuan data identitas pernikahan .

\section{HASIL PEMBAHASAN}

Menurut Drs. Lukman Hakim pemalsuan data sering terjadi disetiap KUA berdasarkan pengalaman beliau selama menjabat kepala KUA di berbagai wilayah, pemalsuan data terjadi karena oknum yang tidak bertanggung jawab yang membantu masyarakat dalam melakukan tindakan pemalsuan data. Ketentuan mengenai sanksi pidana dalam perkawinan termuat dalam Undang-undang No. 1 Tahun 1974 pasal 45 tentang Ketentuan pidana pada perkawinan

(1) Kecuali apabila ditentukan lain dalam peraturan perundang-undangan yang berlaku, maka : a. Barang siapa yang melanggar ketentuan yang diatur dalam pasal 3, 10 ayat (3), 40 peraturan pemerintah ini dihukum dengan hukuman denda setinggi-tingginya Rp.7500,-

b. Pegawai pencatat yang melanggar ketentuan yang diatur dalam pasal $6,7,8,9,10$ ayat $(1), 11,13,44$ peraturan pemerintah ini dihukum dengan hukuman kurungan selama 3 bulan atau denda setinggitingginya Rp.7500,-

(2) Tindak pidana yang dimaksud dalam ayat (1) diatas merupakan pelanggaran.

Kitab Undang-undang Hukum perdata (KUHP) pasal 279 dan pasal 280 yang menjelaskan tentang larangan melakukan tindakan pemalsuan identitas atau kejahatan dalam perkawinan yang berbunyi sebagai berikut: ${ }^{27}$

\section{Pasal 279}

1. Di ancam dengan pidana selama lima tahun:

a. Barang siapa yang mengadakan perkawinan padahal mengetahui bahwa perkawinan yang telah ada menjadi penghalang yang sah untuk itu;

b. Barang siapa mengadakan perkawinan padahal mengetahui bahwa perkawinan atau perkawinan-perkawinan pihak lain menjadi penghalang untuk itu.

${ }^{27}$ Andi Hamzah. KUHAP \& KUHP. Jakarta: Rineka Cipta. Cet. ke -1, hlm. 111. 
2. Jika melakukan perbuatan berdasarkan ayat (1) butir 1 berbunyi kepada pihak lain bahwa perkawinan yang telah ada menjadi penghalang yang sah untuk itu, diancam dengan pidana penjara paling lama 7 tahun.

3. Pencabutan hak berdasarkan pasal 35 No.1-5 dapat dinyatakan.

\section{Pasal 280}

"Barang siapa mengadakan perkawinan, padahal sengaja tidak memberitahu kepada pihak lain bahwa ada penghalang yang sah, diancam pidana penjara paling lama lima tahun, apabila kemudian berdasarkan penghalang tersebut perkawinan lalu dinyatakan tidak sah".

Secara bahasa pasal tersebut tidak menyebutkan secara langsung mengenai larangan pemalsuan identitas, tetapi bila diteliti lebih jauh pasal tersebut menyebutkan larangan "penyembunyian perkawinan yang telah ada" artinya bahwa seorang laki-laki maupun perempuan dilarang untuk menyembunyikan perkawinan yang pernah ia lakukan sebelumnya ketika ia akan menikah kembali dan itu sama halnya dengan pemalsuan status yang masuk dalam kategori pemalsuan identitas.

Selanjutnya ada juga larangan pemalsuan Akta Nikah yang merupakan Akta Otentik yang dapat dijadikan bukti dalam mengajukan upaya hukum yang tercantum dalam pasal 263, 264 dan 266 dalam KUHP.

\section{Pasal 263}

1) Barangsiapa membuat surat palsu atau memalsukan surat yang dapat menimbulkan sesuatu hak, perikatan atau pembebasan hutang atau yang diperuntukkan sebagai bukti dari pada sesuatu hal dengan maksud untuk menyuruh orang lain memakai surat-surat tersebut seolah isinya benar dan tidak palsu, diancam jika pemakaian tersebut dapat menimbulkan kerugian karena pemalsuan surat diancam dengan pidana paling lama enam tahun.

2) Diancam dengan pidana yang sama, barangsiapa dengan sengaja memakai surat palsu atau yang dipalsukan seolah-olah sejati, jika pemakaian surat itu dapat menimbulkan kerugian.

\section{Pasal 264}

"Pemalsuan Akta Otentik merupakan salah satu pemalsuan surat yang dapat diancam dengan pidana penjara paling lama delapan tahun".

\section{Pasal 266}

1) Barangsiapa menyuruh memalsukan keterangan palsu ke dalam surat Akta Otentik mengenai suatu hal yang kebenarannya harus dinyatakan oleh Akta itu, dengan maksud untuk memakai atau menyuruh orang lain memakai akta itu seolah-olah keterangannya sesuai dengan kebenaran, diancam jika pemakaian itu dapat menimbulkan kerugian dengan pidana penjara paling lama lima tahun.

2) Diancam dengan pidana yang sama, barangsiapa dengan sengaja memakai akta tersebut seolah-olah 
isinya sesuai dengan kebenaran, jika karena pemakaian tersebut dapat menimbulkan kerugian.

Pemalsuan dalam perkawinan itu tidak hanya sebatas pada pemalsuan usia dan status saja tetapi pemalsuan Akta Nikah juga termasuk ke dalamnya. Berdasarkan bunyi dari pasal-pasal di atas pemalsuan Akta Nikah maupun surat-surat lainnya merupakan suatu pelanggaran yang dapat dijatuhi hukuman penjara karena hal tersebut dapat mengakibatkan kerugian pada orang lain.

Akibat hukum yang terjadi apabila seseorang melakukan pemalsuan data administrasi pernikahan adalah pernikahan tersebut bisa dibatalkan oleh KUA, melalui pengadilan agama. Pembatalan pernikahan adalah mekanisme yang dijamin hukum. Pasal 22 UU No. 1 Tahun 1974 tentang Perkawinan menyebut tegas bahwa 'perkawinan dapat dibatalkan apabila para pihak tidak memenuhi syarat-syarat untuk melangsungkan perkawinan'. Permohonan pembatalan dapat diajukan isteri atau suami. Dari sisi formal ketentuan UU Perkawinan, tentu Anda berhak mengajukan pembatalan perkawinan. Anda bisa membaca artikel 'Ingin Membatalkan Perkawinan Setelah 5 Hari Menikah'. Pasal 72 ayat (2) Kompilasi Hukum Islam menambahkan frasa 'penipuan atau salah sangka', sehingga menjadi:

"Seorang suami atau isteri dapat mengajukan permohonan pembatalan perkawinan apabila pada waktu berlangsungnya perkawinan terjadi penipuan atau salah sangka mengenai diri suami atau isteri”.
Menurut H. Abdul Manan, biasanya penipuan itu dilakukan dalam bentuk pemalsuan identitas, misalnya mengakui perjaka padahal sudah pernah menikah. Penipuan bisa dilakukan suami, bisa pula oleh isteri. ${ }^{28}$ Adapun alasan hukum yang menyebabkan pernikahan bisa di batalkan adalah sebagai berikut:

1. Perkawinan batal apabila: ${ }^{29}$

a. Suami melakukan perkawinan, sedang ia tidak berhak melakukan akad nikah karena sudah mempunyai empat orang istri, sekalipun salah satu diantaranya itu dalam iddah talak raj'i.

b. Seseorang menikahi bekas istrinya yang telah dili'annya

c. Seseorang menikahi bekas istrinya yang pernah dijatuhi tiga kali talak olehnya, kecuali bila bekas istri tersebut pernah menikah dengan pria lain yang kemudian bercerai lagi ba'da al dukhul dari pria (berjima') tersebut dan telah habis masa iddahnya.

d. Perkawinan dilakukan antara dua orang yang mempunyai hubungan darah semanda dan sesusuan sampai derajat tertentu yang menghalangi perkawinan menurut pasal 8 Undang-undang No. 1 tahun 1974 yaitu :

${ }^{28}$ H. Abdul Manan. 2006. Aneka Masalah Hukum Perdata Islam di Indonesia. Jakarta: Kencana. hlm. 66.

${ }^{29}$ Pasal 70 Instruksi Presiden Nomor 1 Tahun 1991 tentang Penyebarluasan Kompilasi Hukum Islam (“KHI”). 
1. berhubungan darah dalam garis keturunan lurus kebawah atau keatas

2. berhubungan darah dalam garis keturunan menyamping yaitu dengan saudara orang tua dan antara seorang dengan saudara neneknya

3. berhubungan semenda, yaitu mertua, anak tiri, menantu dan ibu atau ayah istri

4. berhubungan sesusuan, yaitu orang tua sesusuan, anak sesusuan saudara sesusuan dan bibi atau paman sesusuan.

e. Istri adalah saudara kandung atau sebagai bibi atau kemenakan dari istri atau istri-istrinya.

2. Perkawinan dapat dibatalkan apabila: ${ }^{30}$

a. Seorang suami melakukan poligami tanpa izin dari Pengadilan Agama;

b. Perempuan yang dikawini ternyata kemudian diketahui masih menjadi istri pria lain yang mafqud (hilang);

c. Perempuan yang dikawini ternyata masih dalam iddah dari suami lain;

d. Perkawinan yang melanggar batas umur perkawinan sebagaimana ditetapkan dalam Pasal 7 Undangundang No. 1 Tahun 1974;

e. Perkawinan dilangsungkan tanpa wali atau dilaksanakan oleh wali yang tidak berhak; f. Perkawinan yang dilaksanakan dengan paksaan.

Pernikahan dalam Islam memiliki kedudukan yang sangat mulia, karena setiap orang Islam sangat dianjurkan untuk menikah sebagai bagian dari fitrah manusia. Prinsip syariah dalam hukum pernikahan sudah diatur didalah fiqih munakahat, diantaranya adalah diatur mengenai rukun dan syarat dalam pelaksanaan pernikahan. Negara Indonesia mengatur dan membukukan ketentuan hukum fiqih pernikahan dari berbagai pendapat atau mazhab dalam satu buku yang disebut dengan Undang-undang Kompilasi Hukum Islam (KHI).

Undang-undang Kompilasi Hukum Islam Bab II pasal 4 dijelaskan bahwa perkawinan adalah sah apabila dilakukan menurut hokum islam sesuai dengan pasal 2 ayat (1) Undang-undang No. 1 tahun 1974tentang perkawinan. ${ }^{31}$ Pasal 5 ayat (1) KHI dijelaskan bahwa agar terjamin ketertiban perkawinan bagi masyaratkat Islam setiap perkawianan harus dicatat. Ayat (2) menjelaskan bahwa pencatatan tersebut pada ayat (1) dilakukan oleh pegawai pencatat nikah sebagaimana yang diatur dalam Undang-undang No.22 tahun 1946 jo Undang-undang No.32 tahun 1954.

Pada prinsipnya setiap masyarakat yang akan melakukan pencatatan pernikahan harus melengkapi dokumen persyaratan administrasi pencatatan pernikahan dan menyerahkannya kepada petugas pencatat nikah yang ada di wilayahnya dalam hal ini yang dimaksud adalah Kantor Urusan Agama (KUA) yang 
ada di wilayah kecamatan masing-masing. Diantara dokumen yang harus dilengkapi adalah berkaitan dengan identitas calon pengantin yang sesuai dengan dokumen catatan sipil baik berupa Kartu Tanda Penduduk (KTP), Kartu Keluarga (KK) atau Akta Kelahiran.

Identitas dalam pencatatan pernikahan menurut Drs. Lukman Hakim.M.Si selaku kepala KUA Kecamatan Citeureup adalah terdiri dari Nama, Tempat Tanggal Lahir, Agama, Jenis Kelamin, Status, dan Alamat. Pada pelaksanaanya banyak masyarakat yang melakukan kecurangan atau memalsukan dokumen identitasnya dikarenakan ada hal-hal tertentu yang menghalangi persyaratan pencacatan nikah, diantanya adalah berkaitan dengan status perkawinan seseorang, apabila calon pengantin berstatus duda atau janda maka harus melampirkan surat keterangan atau akta cerai atau salinan putusan pengadilan.selanjutnya berkaitan dengan tanggal lahir yang terdiri dari tanggal bulan dan tahun lahir calon pengantin, petugas pencatat nikah akan memeriksa berkenaan dengan tanggal, bulan dan tahun lahir calon pengantin untuk mengetahui usia calon pengantin sebagaimana yang di atur dalam Undang-undang No.1 Tahun 1974 tentang perkawinan pasal 7 ayat (1) bahwa perkawinan hanya diizinkan jika pihak pria sudah mencapai usia 19 tahun dan pihak wanita sudah mencapai umur 16 tahun. ${ }^{32}$ Ayat (2) menjelaskan bahwa dalam penyimpangan tersebut terhadap ayat (1) pasal ini dapat meminta dispensasi kepada pengadilan agama. pada pelaksanaanya

\footnotetext{
${ }^{32}$ Undang-undang No.1 Tahun 1974 tentang perkawinan. hlm. 4.
}

apabila calon pengantin belum mencapai usia yang di jelaskan di atas banyak masyarakat yang memanipulasi data tersebut dan merubahnya.

Prinsip dasar dalam syari'at Islam menurut Drs.lukman Hakim bahwa "Akad pernikahan tetap sah, apabila memenuhi syarat dan rukunnya." Adapun adanya nya pemalsuan data selama tidak ada pihak ketiga yang menggugat atau melakukan pengaduan maka pernikahan tersebut tetap sah dan tidak membatalkan akad. ${ }^{33}$ Ada syarat yang menentukan ke absahan akad nikah, memberikan konsekwensi sah tidaknnya akad nikah, dan bisa membatalkan akad apabila ada salah satu syarat yang tertinggal. ${ }^{34}$ Adapun hal-hal yang meyebabkan akad pernikahan batal dalam syariat Islam apabila dalam pernikahan tersebut calon pengantin mengajuakan syarat-syarat illegal yang mengandung unsur memerintahkan apa yang dilarang Allah dan melarang apa yang diperintahkan-Nya, atau meng halalkan apa yang diharamkannya, dan mencederai tujuan pernikahan. ${ }^{35}$

Berdasarkan penjelasan di atas penulis berkesimpulan bahwa status hukum pernikahan yang didalamnya ada pemalsuan data identitas pada persyaratan administrasi pernikahan tetap sah sesuai

${ }^{33}$ Lukman hakim, Kepala KUA Kecamatan Citeureup. Wawancara Pribadi. Bogor 14 Juni 2017.

${ }^{34}$ Kamal abu malik. 2007. shahih fiqh AsSunnah Wa adilatu wa Thaudih Madzahib AlImmah, Alih bahasa Oleh Khairul Amru Harahap, Shahih Fiqih Sunnah, Jakarta: Pustaka Azzam. cet Ke- 5. hlm 203.

${ }^{35}$ Kamal abu malik. 2007. Shahih fiqh AsSunnah Wa adilatu wa Thaudih Madzahib AlImma. hlm. 239. 
ajaran islam apabila syarat dan rukun pernikahnnya terpenuhi. Maka apabila ada pihak ketiga yang menggugat dan melaporkan pemalsuan tersebut maka KUA bisa membatalkan pernikahan tersebut melalui pengadilan Agama sebagaimana yang dijelaskan dalam KHI pasal 73 ayat 3 bahwa diantara yang dapat mengajukan permohonan pembatalan nikah adalah pejabat berwenang yang mengawasi pelaksanaan perkawinan menurut Undang-undang. ${ }^{36}$

\section{KESIMPULAN}

Berdasarkan uraian dan penelitian penulis dapat disimpulkan bahwa Pemalsuan data identitas dalam perkawinan adalah suatu upaya penyelewengan atau penyimpangan yang dilakukan oleh seseorang untuk memalsukan data-data baik berupa status, tanda-tanda, ciri-ciri maupun keadaan khusus seseorang atau jati diri yang dinilai sebagai suatu tindak pidana berupa kebohongan kepada pejabat Negara yang tujuan nya untuk bisa melangsungkan perkawinan.Berdasarkan UU No.1 tahun 1974 dijelaskan bahwa pencatatan pernikahan merupakan bagian penting dari sebuat peristiwa pernikahan yang dilakukan sebagai upaya pengawasan dan pembuktian telah diadakannya suatu perkawinan.

Status hukum pernikahan yang didalamnya ada pemalsuan data identitas pada persyaratan administrasi pernikahan tetap sah sesuai ajaran Islam apabila syarat dan rukun pernikahnnya terpenuhi. Maka apabila ada pihak ketiga yang menggugat dan melaporkan pemalsuan tersebut maka KUA bisa membatalkan pernikahan tersebut melalui pengadilan Agama sebagaimana yang dijelaskan dalam KHI pasal 73 ayat 3 bahwa diantara yang dapat mengajukan permohonan pembatalan nikah adalah pejabat berwenang yang mengawasi pelaksanaan perkawinan menurut Undang-undang.

\section{DAFTAR PUSTAKA}

Shabihi, Abdurahman Ash-. 2003. Petunjuk praktis dan fatwa pernikahan. Jakarta: Najla Press.

Asqalani, Ibnu Hajar Al-. 2013. Bulughul Maram dan Dalil-dalil Hukum. Jakarta: Gema Insani.

Bakri, A. Rahman dan Drs. Ahmad Sukarja. 1993. Hukum Perkawinan Menurut Islam, Undang - Undang Perkawinan dan Hukum Perdata $B W$, Jakarta: PT. Hidakarya Agung.

Direktorat Jendral Bimbingan Masyarakat Islam dan Penyelangaraan Haji. 2005. Tatacara dan Mekanisme Pengurusan Pekawinan dan Rujuk di Indonesia. Jakarta: Departemen agama RI.

Hamzah, Andi. KUHAP \& KUHP. Jakarta: Rineka Cipta, $t$.

Al Hafnawi, Dr. Muhammad Ibrahim. Al Mausu'ah Al Fiqiyyah Al Muyassarah: Az-Zawaj (mansoura: maktabah Aliman, $t$ t.)

\footnotetext{
${ }^{36}$ Kompilasi Hukum Islam. hlm. 354.
} 
Manan, H. Abdul. 2006. Aneka Masalah Hukum Perdata Islam di Indonesia. Jakarta: Kencana.

Malik, Kamal Abu. 2007. Shahih Fiqh AsSunnah Wa Adilatu Wa Thaudih Madzahib Al-Immah, Alih bahasa Oleh Khairul Amru Harahap. Jakarta: Pustaka Azzam.
Usman, Muhammad Rafa'at. 2017. Fiqih Khitbah dan nikah (edisi perempuan). alih bahasa Ahmad Zaeni Dachlan, Depok: Fhatan Media Prima.

Yazid, Abdul Qadir. 2014. Panduan Keluarga Sakinah .Jakarta: Pustaka Imam Syafi' I. 
